\title{
PENGARUH EXPERIENTIAL MARKETING DAN BRAND TRUST TERHADAP LOYALITAS PELANGGAN MELALUI KEPUASAN PELANGGAN SEBAGAI VARIABEL INTERVENING \\ (Studi Kasus Pada Pengguna Smartphone Samsung Di Kota Yogyakarta)
}

\author{
Agustina Susanti ${ }^{1}$, Henny Welsa ${ }^{2}$, Putri Dwi Cahyani ${ }^{3}$ \\ Fakultas Ekonomi Universitas Sarjanawiyata Tamansiswa Yogyakarta \\ E-mail: asusanti210@gmail.com
}

\begin{abstract}
INTISARI
Tujuan penelitian ini adalah 1) Menguji dan mengetahui signifikansi pengaruh positif Experiential Marketing terhadap Kepuasan Pelanggan, 2) Menguji dan mengetahui signifikansi pengaruh positif Kepercayaan Merek terhadap Kepuasan Pelanggan, 3) Menguji dan mengetahui signifikansi pengaruh positif Experiential Marketing terhadap Loyalitas Pelanggan, 4) Menguji dan mengetahui signifikansi pengaruh positif Kepercayaan Merek terhadap Loyalitas Pelanggan, 5) Menguji dan mengetahui signifikansi pengaruh positif Kepuasan Pelanggan terhadap Loyalitas Pelanggan.

Penelitian ini tergolong dalam jenis penelitian kuantitatif. Populasi penelitian ini adalah pengguna smartphone Samsung di Kota Yogyakarta. Untuk menentukan sampel, peneliti menggunakan kuesioner. Sampel penelitian didapatkan melalui kuesioner yang dibagikan oleh peneliti kepada responden di kawasan Kota Yogyakarta. Anggota sampel yang digunakan adalah 100 responden. Teknik analisis data menggunakan uji kualitas data, statistik deskriptif, uji asumsi klasik yang terdiri dari uji normalitas, uji multikolonieritas, uji heteroskedastisitas dan uji regresi linier berganda.

Hasil penelitian menunjukkan bahwa 1) Experiential Marketing berpengaruh signifikan positif terhadap Kepuasan Pelanggan, 2) Kepercayaan Merek berpengaruh signifikan positif terhadap Kepuasan Pelanggan, 3) Experiential Marketing berpengaruh signifikan positif terhadap Loyalitas Pelanggan, 4) Kepercayaan Merek tidak berpengaruh signifikan terhadap Loyalitas Pelanggan, 5) Kepuasan Pelanggan berpengaruh signifikan positif terhadap Loyalitas Pelanggan.
\end{abstract}

Kata Kunci: Experiential Marketing, Kepercayaan Merek, Kepuasan Pelanggan, Loyalitas Pelanggan.

\section{ABSTRACT}

The purpose of this study is 1) Test and determine the significance of the positive influence of Experiential Marketing on Customer Satisfaction, 2) Test and know the significance of the positive influence of Brand Trust on Customer Satisfaction, 3) Test and know the significance of the positive influence of Experiential Marketing on Customer Loyalty, 4) Test and know the significance of the positive influence of Brand Trust on Customer Loyalty, 5) Test and know the significance of the positive influence of Customer Satisfaction on Customer Loyalty.

This research belongs to the type of quantitative research. The population of this research is Samsung smartphone users in the city of Yogyakarta. To determine the sample, researchers used a questionnaire. The research sample was obtained through a questionnaire distributed by researchers to respondents in the Yogyakarta City area. The sample members used were 100 respondents. Data analysis techniques using data quality tests, descriptive statistics, classic assumptions test consisting of normality tests, multicollinearity tests, heteroscosity tests and multiple linear regression tests.

The results showed that 1) Experiential Marketing had a significant positive effect on Customer Satisfaction, 2) Brand Trust had a significant positive effect on Customer 
Satisfaction, 3) Experiential Marketing had a significant positive effect on Customer Loyalty, 4) Brand Trust had a not significant effect on Customer Loyalty, 5) Customer Satisfaction has a significant positive effect on Customer Loyalty.

Keywords: Experiential Marketing, Brand Trust, Customer Satisfaction, Customer Loyalty.

\section{PENDAHULUAN}

Era industrialisasi 4.0 merubah presepsi masyarakat akan smartphone yang tidak hanya sebagai alat komunikasi. Saat ini smartphone menjadi kebutuhan akan aktivitas masyarakat karena dengan menggunakan smartphone menjadikan mudah dan efisien dalam membantu pekerjaan dan mempermudah kegiatan sehari-hari. Perkembangan tekhnologi smartphone dari sejak pertama keluar hingga sekarang sangatlah pesat sehingga membuat perusahaan-perusahaan pembuat handphone haruslah bersaing ketat dan mengeluarkan produk-produk terbarunya yang dapat menarik para konsumen untuk membeli produk mereka.

Pertumbuhan perusahaan bisa dicapai ketika perusahaan berhasil mengatasi persaingan dan meningkatkan penjualan nya. Penjualan yang terus meningkat menunjukkan bahwa konsumen memiliki loyalitas terhadap produk yang dipasarkan. Karena itu perusahaan akan terus berupaya untuk meningkatkan loyalitas konsumen, sehingga perusahaan akan mendapatkan konsumen yang potensial dalam arti konsumen yang bisa diharapkan kesetiaannya untuk selalu membeli produk di masa depan.

Loyalitas pelanggan merupakan faktor penting keberlangsungan perusahaan terutama pada pertumbuhan dan perkembangan perusahaan di masa yang akan datang, selain itu mempertahankan pelanggan lama membutuhkan biaya yang lebih murah dibandingkan dengan biaya mencari pelanggan baru. Lovelock dan Wright (2007:133) mendefinisikan loyalitas sebagai keputusan pelanggan untuk secara suka rela terus berlangganan dengan perusahaan tertentu dalam jangka waktu yang lama. Persaingan yang semakin ketat dan berkembangnya ekspektasi pelanggan mendorong perusahaan untuk lebih memfokuskan pada upaya untuk mempertahankan pelanggan yang ada. Loyalitas pelanggan dapat dicapai apabila perusahaan berhasil dalam memberikan kepuasan. Saat ini banyak perusahaan yang berpacu dalam memberikan kepuasan konsumen untuk mempertahankan market share sekaligus mengatasi gejolak persaingan yang semakin meningkat.

Menurut Kotler dan Keller (2009:177) menyatakan kepuasan adalah perasaan senang atau kecewa, puas atau tidak puas seorang konsumen setelah membandingkan antara kinerja (hasil) produk yang diterima dengan kinerja (hasil) diharapkan, apabila kinerja (hasil) dibawah harapan maka kosumen tidak puas, apabila kinerja (hasil) sebanding dengan harapan maka konsumen puas, dan apabila kinerja (hasil) melebihi harapan maka konsumen sangat puas. Wilkie dalam Tjiptono (2001:24) menyebutkan kepuasan merupakan tanggapan emosional dalam mengevaluasi atas pengalaman menggunakan suatu produk atau jasa.

Untuk meningkatkan kepuasan konsumen perusahaan dituntut untuk meninjau kembali mengenai konsep pemasaran dan strategi pemasaran yang selama ini digunakan. Evolusi perubahan konsumen di era global harus diikuti dengan perubahan pendekatan pemasaran experiential yang lebih merefleksikan pemenuhan kebutuhan dan keinginan konsumen secara cepat dan tepat. Salah satu cara yang bisa dilakukan pemasar adalah menerapkan konsep experiential marketing yang ditemukan oleh Schmitt (1999) bahwa menurutnya pelanggan harus dirangsang secara rasional dan emosional karena pelanggan membeli suatu produk tidak hanya untuk fungsinya semata, tetapi juga untuk kesenangan atau hiburan.

Selain experiential marketing faktor lainnya yang mempengaruhi loyalitas konsumen adalah kepercayaan, menurut Lau dan Lee (1999) menjelaskan kepercayaan terhadap merek merupakan keinginan konsumen untuk mempercayai merek dengan segala konskuensinya, ini terjadi karena adanya ekspektasi yang dijanjikan oleh suatu merek produk dalam memberikan 
hasil yang positif bagi pelanggan. Seorang konsumen akan merasa puas dan kepercayaan bisa meningkat apabila semua ekspektasi dan janji mengenai produk atau jasa terpenuhi.

\section{TINJAUAN PUSTAKA DAN PENGEMBANGAN HIPOTESIS}

\section{Experiential Marketing}

Menurut Kertajaya, (2010:23) Experiential marketing adalah suatu konsep pemasaran yang bertujuan membentuk pelanggan yang loyal dengan cara menyentuh emosi pelanggan dengan menciptakan pengalaman-pengalaman positif dan memberikan suatu feeling yang positif terhadap jasa dan produk mereka. Experiential marketing memberikan kesempatan kepada pelanggan dengan cara sensorik untuk terlibat dan berinteraksi dengan merek, produk, dan jasa.

\section{Brand Trust}

Brand trust menurut Susilowati dan Sumarto (2010: 57) adalah keyakinan pelanggan yang tetap dijaga industri agar terus mempercayai bahwa merek tersebut dapat memenuhi kebutuhan pelanggan.

\section{Kepuasan Pelanggan}

Menurut Kotler dan Keller (2009:164) kepuasan pelanggan adalah perasaan pelanggan yang puas atau kecewa yang dihasilkan dari membandingkan kinerja yang dipersepsikan produk (atau hasil) dengan ekspetasi pelanggan. Seperti dijelaskan dalam definisi tersebut, kepuasan merupakan fungsi dari persepsi atau kesan atas kerja dan harapan.

\section{Pelanggan}

Loyalitas menurut Griffin dalam Noegroho, Suharyono dan Kumadji (2013) adalah wujud perilaku dari unit-unit pengambil keputusan untuk melakukan pembelian secara terus menerus terhadap barang atau jasa suatu perusahaan yang dipilih.

\section{Pengembangan Hipotesis}

Pengaruh Experiential Marketing terhadap Kepuasan Pelanggan

Oeyono dan Dharmayanti (2013) yang menyatakan bahwa experiential marketing penting diberikan guna meningkatkan kepuasan pelanggan, dan mendukung penelitian Tjiptono, Chandra \& Adriana (2012) yaitu yang memperlihatkan bahwa antara experiential marketing dan kepuasan pelanggan mempunyai pengaruh yang kuat.

\section{Brand Trust terhadap Kepuasan Pelanggan}

Arfianti (2014) yang menyatakan bahwa kepercayaan mampu mempengaruhi tingkat kepuasan dengan cara yang berbentuk pelayanan yang tanggap terhadap keluhan dan terbuka dalam proses transaksi, dan membentuk integritas perusahaan. Jadi dapat disimpulkan bahwa Brand Trust berpengaruh positif dan signifikan terhadap Kepuasan Pelanggan.

\section{Pengaruh Experiential Marketing terhadap Loyalitas Pelanggan}

Artanti \& Wulansari (2014) yang menyatakan bahwa variabel experiental marketing berpengaruh secara signifikan terhadap loyalitas pelanggan. Serta mendukung hasil penelitian Oeyono dan Dharmayanti (2013) yang menyatakan bahwa experiental marketing mempengaruhi secara signifikan terhadap loyalitas sebuah perusahaan.

\section{Pengaruh Brand Trust terhadap Loyalitas Pelanggan}

Agustina, Fauzi, dan Nuralam (2018) menunjukkan bahwa kepercayaan merek berpengaruh signifikan terhadap loyalitas pelanggan. Kepercayaan terbentuk jika suatu merek mampu 
memenuhi harapan pelanggan atau bahkan melebihi harapan konsumen dan memberikan jaminan kualitas.

\section{Pengaruh Kepuasan Pelanggan Terhadap Loyalitas Pelanggan}

Kepuasan sering kali dipandang sebagai dasar munculnya loyalitas. Singh (2006) terdapat korelasi positif antara kepuasan pelanggan dengan loyalitas pelanggan dan penelitian Yang dan Peterson (2004) bahwa kepuasan pelanggan akan mengarahkan pelanggan untuk menjadi pelanggan yang loyal.

\section{METODE PENELITIAN}

Penelitian ini bersifat kuantitatif, populasi dalam penelitian ini adalah pengguna smartphone Samsung di Kota Yogyakarta. Jumlah sampel yang diambil sebagai responden dalam penelitian ini adalah sebanyak 100 responden. Teknik pengambilan sampel yang digunakan dalam penelitian ini adalah accidental purposive sampling.

\section{HASIL DAN PEMBAHASAN Karakteristik Responden}

Tabel 1. Karakteristik Responden

\begin{tabular}{lcc}
\hline Kategori & Frekuensi & Prosentase \\
\hline Jenis Kelamin & & \\
\hline Laki-Laki & 54 & 54.0 \\
Perempuan & 46 & 46.0 \\
\hline Umur & & \\
\hline $17-22$ & 63 & 63.0 \\
$23-28$ & 36 & 36.0 \\
$29-34$ & 1 & 1.0 \\
\hline Intensitas Penggunaan & & \\
\hline 2 kali & 58 & 58.0 \\
3 kali & 23 & 23.0 \\
$<4$ kali & 19 & 19.0 \\
\hline
\end{tabular}

Hasil dari tabel 1 menunjukkan bahwa dari 100 responden, berjenis kelamin laki-laki yaitu sebanyak 54 dan yang berjenis kelamin perempuan sebanyak 46, usia 17-22 tahun yaitu sebanyak 63 orang, usia 23-28 tahun sebanyak 36 orang, usia 29-34 tahun sebanyak 1 orang, Intensitas penggunaan 2 kali yaitu sebanyak 58 orang, Intensitas penggunaan 3 yaitu sebanyak kali 23 orang, Intensitas penggunaan $<4$ kali yaitu sebanyak 19 orang.

\section{Hasil Uji Instrumen}

Tabel 2. Uji Validitas dan Reliabilitas

\begin{tabular}{|c|c|c|c|c|c|c|c|}
\hline \multicolumn{2}{|c|}{$\begin{array}{r}\text { Experiential } \\
\text { Marketing }\end{array}$} & \multicolumn{2}{|c|}{ Brand Trust } & \multicolumn{2}{|c|}{ Kepuasan Pelanggan } & \multicolumn{2}{|c|}{$\begin{array}{l}\text { Loyalitas } \\
\text { Pelanggan }\end{array}$} \\
\hline EM & 32 & BT & 24 & $\mathrm{KP}$ & 42 & LP & 00 \\
\hline EM & 21 & BT & 38 & KP & 50 & LP & 44 \\
\hline EM & 31 & BT & 50 & $\mathrm{KP}$ & 57 & LP & 47 \\
\hline EM & 59 & BT & 89 & KP & 54 & LP & 34 \\
\hline EM & 44 & & & & & LP & 94 \\
\hline EM & 06 & & & & & LP & 85 \\
\hline EM & 79 & & & & & & \\
\hline
\end{tabular}




\begin{tabular}{llll} 
EM & 21 & & \\
EM & 93 & & \\
EM & 71 & \multicolumn{4}{c}{ Cronbach's Alpha } \\
\hline \multicolumn{5}{c}{0,741} \\
\hline
\end{tabular}

Tabel diatas menunjukkan bahwa semua item pernyataan indikator dari variabel Experiential Marketing (X1), Brand Trust (X2), Kepuasan Pelanggan (Z), dan Loyalitas Pelanggan (Y) mempunyai nilai lebih besar dari $\mathrm{r}$ table $(0,1654)$. Dengan demikian semua item pernyataan untuk semua variabel dinyatakan valid.

Serta semua variabel Experiential Marketing (X1), Brand Trust (X2), Kepuasan Pelanggan (Z), dan Loyalitas Pelanggan (Y) memiliki nilai cronbach's alpha lebih besar 0,6 . Hal ini berarti bahwa alat ukur tersebut reliable.

\section{Hasil Uji Asumsi Klasik}

Tabel 3. Asumsi Klasik

\begin{tabular}{ccccccc}
\hline & \multicolumn{2}{c}{ Variabel } & Normalitas & \multicolumn{2}{c}{ Multikolonieritas } & Heteroskedastisitas \\
\hline & Bebas & Terikat & Sig. & Tol. & VIF & Sig. (two tailed) \\
\hline \multirow{2}{*}{1} & EM & \multirow{2}{*}{ KP } & \multirow{2}{*}{0.407} & 0.395 & 2.529 & 0,070 \\
& BT & & & 0.395 & 2.529 & 0,833 \\
\hline \multirow{2}{*}{2} & EM & \multirow{2}{*}{ LP } & \multirow{2}{*}{0.503} & 0.361 & 2.771 & 0,214 \\
& BT & \multirow{2}{*}{} & & 0.294 & 3.398 & 0,037 \\
& KP & & & 0.354 & 2.823 & 0,233 \\
\hline
\end{tabular}

Tabel 3 menunjukkan model regresi tidak mengalami multikolonieritas (tolerance $>0,10$ dan VIF < 10), tidak mengalami heteroskedastisitas dan data terdistribusi normal (Kolmogorov-Smirnovtest memiliki asymp sig > 0,05). Dengan demikian ketiga model regresi memenuhi persyaratan untuk diuji regresi.

\section{Hasil Uji Hipotesis}

Tabel 4. Pengujian Hipotesis

\begin{tabular}{ccccccc}
\hline Hip. & \multicolumn{2}{c}{ Variabel } & \multicolumn{2}{c}{ Stand. Coeff. } & & \multicolumn{2}{c}{ Koef. Detr. } \\
& Bebas & Terikat & Beta & T & Sig. & Adj. $\boldsymbol{R}$ Sq \\
\hline H1 & EM & \multirow{2}{*}{ KP } & 0.293 & 3.047 & 0.003 & \multirow{2}{*}{0,639} \\
H2 & BT & & 0.555 & 5.771 & 0.000 & \\
\hline H3 & EM & & 0.504 & 6.680 & 0.000 & \\
H4 & BT & LP & 0.100 & 1.201 & 0.233 & 0.797 \\
H5 & KP & & 0.367 & 4.828 & 0.000 & \\
\hline
\end{tabular}

Hasil pengujian hipotesis table 4 menunjukkan bahwa H1 menghasilkan nilai t hitung positif dan signifikan sebesar 3,047 dan 0,003 >0,05 nilai tersebut dapat membuktikan bahwa Ho ditolak yang berarti bahwa Experiential Marketing berpengaruh terhadap Kepuasan Pelanggan. H2 menghasilkan nilai t hitung positif dan signifikan sebesar 5,771 dan $0,000>0,05$ nilai tersebut dapat membuktikan bahwa Ho ditolak yang berarti bahwa Brand Trust berpengaruh terhadap Kepuasan Pelanggan. H3 menghasilkan nilai t hitung positif dan signifikan sebesar 6,680 dan $0,000<0,05$ nilai tersebut dapat membuktikan bahwa Ho ditolak yang berarti Experiential Marketing berpengaruh terhadap Loyalitas Pelanggan. H4 menghasilkan nilai t hitung 1,201 lebih kecil dari t tabel 1,98472 dan 0,233>0,05 nilai tersebut membuktikan bahwa Ho diterima yang berarti bahwa Brand Trust tidak berpengaruh 
signifikan terhadap Loyalitas Pelanggan. H5 menghasilkan nilai $\mathrm{t}$ hitung positif dan signifikan 4,828 dan 0,000<0,05 nilai tersebut dapat membuktikan bahwa Ho ditolak yang berarti bahwa Kepuasan Pelanggan berpengaruh terhadap Loyalitas Pelanggan.

Pengaruh Experiential Marketing dan Brand Trust menunjukkan adjusted $R$ square sebesar 0,639 hal ini berarti 63,9\% variabel Kepuasan Pelanggan dipengaruhi Experiential Marketing dan Brand Trust sisanya 36,1\% dipengaruhi oleh variabel lain. Adjusted $R$ square sebesar 0,797 hal ini berarti 79,7\% variabel Loyalitas Pelanggan dipengaruhi Experiential Marketing dan Brand Trust sisanya 20,3\% dipengaruhi oleh variabel lain.

\section{Tabel 5. Uji F}

Uji F I

\begin{tabular}{lcc}
\hline Model & F & Sig. \\
\hline Regression & 88.439 & $0.000^{\mathrm{a}}$ \\
\hline Variabel Dependen: Kepuasan & Pelanggan
\end{tabular}

Uji F II

\begin{tabular}{lll}
\hline Model & F & Sig. \\
\hline Regression & 130.475 & 0,000 \\
\hline Variabel Dependen: Loyalitas Pelanggan
\end{tabular}

Berdasarkan tabel 5 nilai signifikan nilai 0,000 atau kurang dari 0,05 maka dapat disimpulkan bahwa experiential marketing, brand trust, dan kepuasan pelanggan secara simultan berpengaruh terhadap loyalitas pelanggan.

\section{Kerangka Pikir Penelitian}

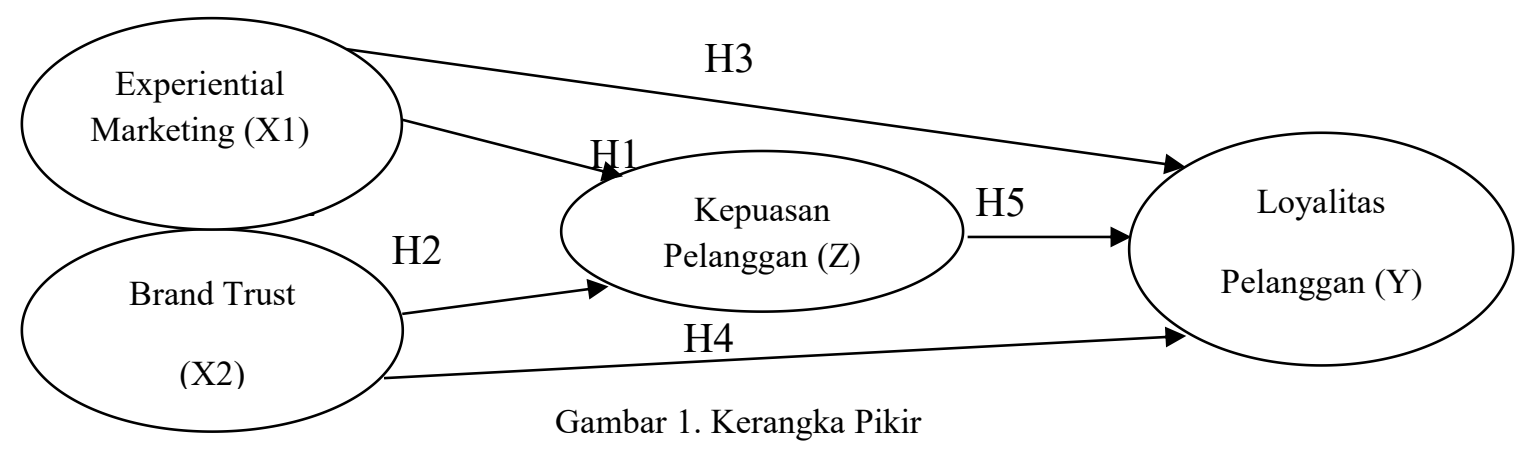

Uji Sobel Test

Tahap I

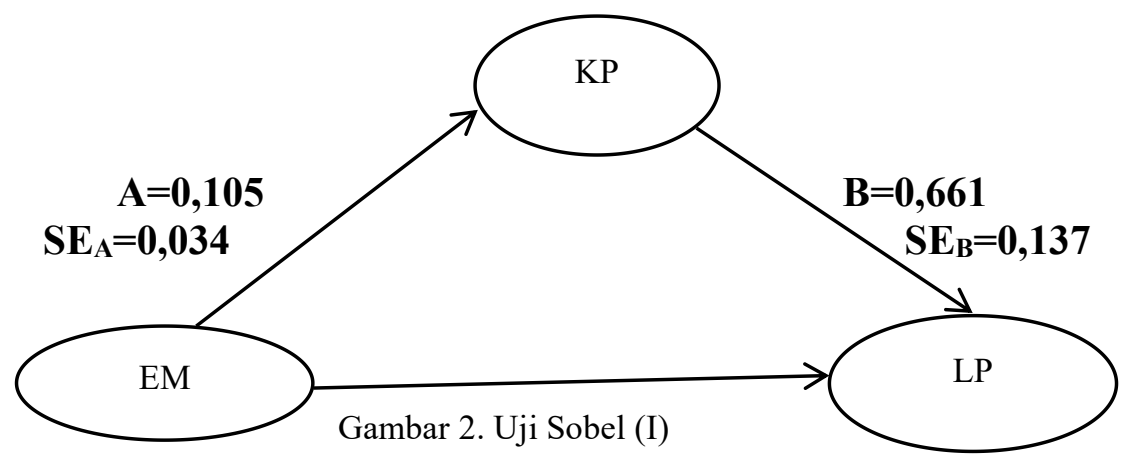

Dari hasil perhitungan sobel test diatas diketahui one-tailed probability 0,0046470 dengan tingkat signifikasi 5\% dari hasil tersebut maka dapat ditarik kesimpulan untuk variabel pengaruh Experiential Marketing terhadap Loyalitas Pelanggan dengan Kepuasan Pelanggan sebagai Variabel Intervening diterima. 


\section{Tahap II}

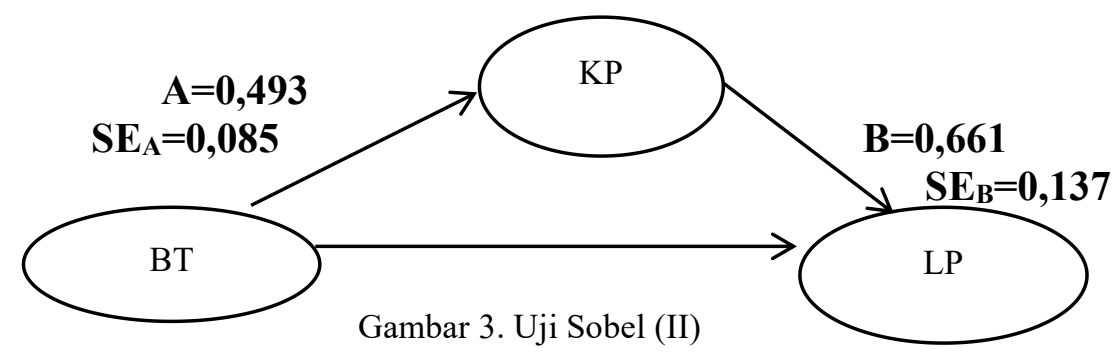

Dari hasil perhitungan sobel test diatas diketahui one-tailed probability 0,00010396 dengan tingkat signifikasi $5 \%$ dari hasil tersebut maka dapat ditarik kesimpulan untuk variabel pengaruh Brand Trust terhadap Loyalitas Pelanggan dengan Kepuasan Pelanggan sebagai Variabel Intervening diterima.

\section{Pembahasan}

\section{Pengaruh Experiential Marketing terhadap Kepuasan Pelanggan}

Hasil penelitian menunjukan bahwa Experiential Marketing berpengaruh secara positif dan signifikan terhadap Kepuasan Pelanggan. Hal ini disebabkan karena pengalaman pemasaran akan membuat pelanggan lebih puas karena bisa secara langsung melihat fisik produk tersebut dan akan membuat semakin yakin dengan produk tersebut

Hasil penelitian ini juga mendukung penelitian yang sudah dilakukan oleh Oeyono dan Dharmayanti (2013) yang menyatakan bahwa experiential marketing penting diberikan guna meningkatkan kepuasan pelanggan, dan mendukung penelitian Tjiptono, Chandra \& Adriana (2012) yaitu yang memperlihatkan bahwa antara experiential marketing dan kepuasan pelanggan mempunyai pengaruh yang kuat.

\section{Pengaruh Brand Trust terhadap Kepuasan Pelanggan}

Hasil penelitian menunjukan bahwa Brand Trust berpengaruh secara positif dan signifikan terhadap Kepuasan Pelanggan. Hasil dari penelitian menunjukkan bahwa pelanggan percaya dengan menggunakan smartphone Samsung, Samsung juga selalu mengeluarkan smartphone seri terbaru sesuai dengan kemajuan teknologi yang semakin modern dan yang dibutuhkan oleh pelanggan sehingga membuat pelanggan merasa puas.

Hasil penelitian ini juga mendukung penelitian yang sudah dilakukan oleh Arfianti (2014) yang menyatakan bahwa kepercayaan mampu mempengaruhi tingkat kepuasan dengan cara yang berbentuk pelayanan yang tanggap terhadap keluhan dan terbuka dalam proses transaksi, dan membentuk integritas perusahaan. Jadi dapat disimpulkan bahwa Brand Trust berpengaruh positif dan signifikan terhadap Kepuasan Pelanggan.

\section{Pengaruh Experiential Marketing terhadap Loyalitas Pelanggan}

Hasil penelitian menunjukan bahwa Experiential Marketing berpengaruh secara positif dan signifikan terhadap Loyalitas Pelanggan. Hasil dari penelitian menunjukan bahwa pelanggan menyukai desain produk yang dikeluarkan oleh Samsung dari segi warna, tampilan dan bentuk smartphone beraneka ragam.

Hasil penelitian ini mendukung penelitian Artanti \& Wulansari (2014) yang menyatakan bahwa variabel experiental marketing berpengaruh secara signifikan terhadap loyalitas pelanggan. Serta mendukung hasil penelitian Oeyono dan Dharmayanti (2013) yang menyatakan bahwa experiental marketing mempengaruhi secara signifikan terhadap loyalitas sebuah perusahaan. 


\section{Brand Trust terhadap Loyalitas Pelanggan}

Hasil penelitian menunjukan bahwa Brand Trust tidak berpengaruh signifikan terhadap Loyalitas Pelanggan. Jadi dapat dilihat kenapa Brand Trust tidak berpengaruh signifikan positif terhadap Loyalitas Pelanggan. Hasil dari penelitian tersebut menunjukkan bahwa Samsung tidak memberikan penanganan keluhan yang sesuai dengan apa yang dibutuhkan pelanggannya. Selain itu pelanggan juga tidak melakukan pembelian ulang smartphone Samsung karena selain kualitas produk, pelayanan terhadap pelanggan juga merupakan hal penting yang harus diperhatikan untuk mempertahankan pelanggan agar tidak berpindah ke merek lain.

Hasil penelitian ini konsisten dengan penelitian yang dilakukan oleh Rezki Yunima, Retno Budi Lestari dan Herry Widagdo (2012) yang menyatakan bahwa Brand Trust tidak berpengaruh terhadap Loyalitas Pelanggan.

\section{Pengaruh Kepuasan Pelanggan terhadap Loyalitas Pelanggan}

Hasil penelitian menunjukan bahwa Kepuasan Pelanggan berpengaruh secara positif dan signifikan terhadap Loyalitas Pelanggan. Hasil dari penelitian menunjukan bahwa seiring perkembangan teknologi yang semakin maju Samsung selalu mengeluarkan varian produk yang terbarukan karena menjadi hal penting yang diberikan Samsung untuk memanjakan dan memberikan apa yang dibutuhkan para pelanggannya

Hasil ini juga mendukung penelitian terdahulu yang dilakukan oleh Singh (2006) bahwa terdapat korelasi positif antara kepuasan pelanggan dengan loyalitas pelanggan dan penelitian Yang dan Peterson (2004) bahwa kepuasan pelanggan akan mengarahkan pelanggan untuk menjadi pelanggan yang loyal.

\section{PENUTUP}

\section{Kesimpulan}

Variabel Experiential Marketing berpengaruh positif dan signifikan terhadap Kepuasan Pelanggan hal ini dibuktikan dengan nilai signifikansi yang kurang dari 0,05. Brand Trust berpengaruh positif dan signifikan terhadap Kepuasan Pelanggan hal ini dibuktikan dengan nilai signifikansi yang kurang dari 0,05. Experiential Marketing berpengaruh positif dan signifikan terhadap Loyalitas Pelanggan hal ini dibuktikan dengan nilai signifikansi yang kurang dari 0,05 . Brand Trust tidak berpengaruh signifikan terhadap Loyalitas Pelanggan hal ini ditunjukkan oleh tingkat signifikansinya yang melebihi 0,05 . Kepuasan Pelanggan berpengaruh positif dan signifikan terhadap Loyalitas Pelanggan hal ini dibuktikan dengan nilai signifikansi yang kurang dari 0,05.

\section{Saran}

\section{Bagi Perusahaan}

Sebaiknya perusahaan Samsung memperbaiki cara untuk memberikan pelayanan terhadap pelanggan. Sehingga apa yang disampaikan dapat tersampaikan dan diterima dengan baik oleh pelanggan. Meningkatkan brand trust atau kepercayaan merek yang telah ada saat ini sehingga reputasi yang sudah dijaga saat ini akan terus baik dimasa datang dan dalam mengembangkan produk-produk baru akan lebih baik untuk pelanggan. Hal ini perlu dilakukan karena melihat situasi dunia bisnis dibidang teknologi dalam persaiangan terus meningkat seiring waktu.

\section{Bagi Akademik}

Pada penelitian ini peneliti hanya menguji pengaruh variabel independen (Experiential Marketing, Brand Trust dan Kepuasan Pelanggan) terhadap variabel dependen (Loyalitas Pelanggan) pengguna smartphone Samsung, oleh sebab itu saran peneliti untuk 
peneliti selanjutnya adalah dapat melakukan penelitian yang serupa dengan menambah variasi variabel independen yang dapat mempengaruhi Loyalitas Pelanggan. Dapat dijadikan sebagai bahan pemikiran, pertimbangan atau bahan referensi bagi peneliti lain dalam bidang yang sama untuk melakukan penelitian dalam variabel yang terkait.

\section{DAFTAR PUSTAKA}

Agustina, N., Fauzi DH, A., \& Nuralam, I. P. (2018). PENGARUH KEPUASAN PELANGGAN, BIAYA BERALIH, DAN KEPERCAYAAN MEREK TERHADAP LOYALITAS PELANGGAN (Survei pada Pengguna Kartu Operator Seluler Simpati pada Mahasiswa Jurusan Ilmu Administrasi Bisnis Angkatan 2015/2016 dan 2016/2017 Fakultas Ilmu Administrasi. Jurnal Administrasi Bisnis, 64(1), 92-101.

Arfianti, S. R. (2014). Pengaruh Citra dan Kepercayaan terhadap Loyalitas Nasabah melalui Kepuasan Nasabah. Management Analysis Journal, 3(2).

Artanti, Y., \& Wulansari, D. (2014). Pengaruh Pemasaran Berdasarkan Pengalaman, Pemasaran Emosional Terhadap Loyalitas Pelanggan. Jurnal Ilmu Manajemen, 2(4).

Kertajaya, Hermawan. 2010. Connect! Surving New Wave Marketing. Jakarta : Gramedia

Kotler, Philip, dan Kevin Lane Keller. 2009. Manajemen Pemasaran Jilid 1, edisi Ketiga Belas, Terjemahan Bob Sabran, MM. Jakarta: Penerbit Erlangga.

Lau, G. T., \& Lee, S. H. (1999). Consumers' trust in a brand and the link to brand loyalty. Journal of Market-Focused Management, 4(4), 341-370.

Lovelock, Christopher H. dan Lauren K. Wright. 2007. Manajemen Pemasaran Jasa. Cetakan II. Indeks. Jakarta.

Noegroho, Suharyono et al. (2013). Pengaruh Experiential Marketing dan Brand Trust terhadap kepuasan dan loyalitas pelanggan Survei Pada Pelanggan KFC Cabang Kawi Malang vol 06. Jurnal Administrasi Bisnis, Vol 06.

Oeyono, J., \& Dharmayanti, D. (2013). Analisa Pengaruh Experiential Marketing Terhadap Intervening Variabel Di Tator Cafe Surabaya Town Square. Jurnal Manajemen Pemasaran, 1(2), 1-9.

Schmitt, B. (1999). Experiential marketing. Journal of marketing management, 15(1-3), 53-67.

Singh, S. (2006). Impact of color on marketing. Management decision.

Susilowati, L., \& Sumarto. (2010). Memprediksi Tingkat Obligasi Perusahaan Manufaktur yang Listing di BEI. Jurnal Mitra Ekonomi dan Manajemen Bisnis, Vol 1, No.2.

Tjiptono, Fandy, 2001, Strategi Pemasaran, Edisi Kedua, Andi offset, Yogyakarta

Tjiptono, F., Chandra, G., \& Adriana, D. (2012). Pemasaran strategik. Yogyakarta: Andi.

Yang, Z., \& Peterson, R. T. (2004). Customer perceived value, satisfaction, and loyalty: The role of switching costs. Psychology \& marketing, 21(10), 799-822.

Yunima, R., Lestari, R. B., \& Widagdo, H. (2012). Pengaruh Brand Image , Brand Trust , dan Company Reputation Terhadap Loyalitas Handphone XYZ Di Palembang. Jurnal Bisnis Dan Manajemen, 4(2), 1-9. 